\title{
ROLE OF DIVERSITY MANAGEMENT AND CHARISMATIC LEADERSHIP ON INNOVATION AND PERFORMANCE IN THE GLOBALIZED ERA
}

\author{
PAPEL DA GESTÃO DA DIVERSIDADE E DA LIDERANÇA CARISMÁTICA EM INOVAÇÃO \\ E DESEMPENHO NA ERA GLOBALIZADA \\ PAPEL DE LA GESTIÓN DE LA DIVERSIDAD Y EL LIDERAZGO CARISMÁTICO EN LA \\ INNOVACIÓN Y EL DESEMPEÑO EN LA ERA GLOBALIZADA
}

Zafer Adiguzel $^{1}$

Fatma Sonmez Cakir ${ }^{2}$

\section{Cite as - American Psychological Association (APA)}

Adiguzel, Z., \& Sonmez Cakir, F. (2020, Sept./Dec.). Role of diversity management and charismatic leadership on innovation and performance in the globalized era. International Journal of Innovation - IJI, São Paulo, 8(3), 489-515. https://doi.org/10.5585/iji.v8i3.17595.

\begin{abstract}
Objective of the Study: The purpose of this study was to analyze the relationships between the variables of diversity management, charismatic leadership, innovation speed, innovation performance, and company performance.

Methodology/Approach: A survey study was conducted with 427 employees (both technicians and engineers) working at companies that operated in the manufacturing industry in the scope of the research purpose. SPSS 25 and SPSS AMOS programs were used incrementally, and the acquired data were evaluated and analyzed.

Originality/Relevance: In this research, white-collar workers constituted our sampling group because they play a key role in product innovation. While gathering the analysis data, the first 500 companies registered in Istanbul Chamber of Industry were determined, and manufacturing companies operating in Istanbul constituted the main part of the study.

Main Results: As a result of the analysis, it is understood that diversity management and charismatic leadership have a positive influence on innovation and performance.

Theoretical/Methodological Contribution: In terms of innovation and company performance, the study revealed the mediation effect of charismatic leadership linked to diversity management.

Social/management contributions: In order for organizations to carry out creative and innovative activities, it is very important to effectively manage different ideas and thoughts within organizations. In fact, charismatic leadership positively affects employees, helping them to perform better. Therefore, employees must be actively involved in order to successfully carry out innovation.
\end{abstract}

Keywords: Diversity management. Charismatic leadership. Innovation speed. Innovation performance. Company performance.

\footnotetext{
1 Associate professor. Istanbul Medipol University, Medipol Business School. Istanbul - Turkey. zadiguzel@medipol.edu.tr

${ }^{2}$ Associate professor. Bartin University, Faculty of Economics and Administrative Sciences. Bartin - Turkey. fsonmez@bartin.edu.tr
} 


\section{Resumo}

Objetivo do estudo: O objetivo deste estudo foi analisar as relações entre as variáveis gestão da diversidade, liderança carismática, velocidade de inovação, desempenho inovador e desempenho da empresa.

Metodologia/Abordagem: Foi realizado um estudo survey com 427 funcionários (técnicos e engenheiros) que atuam em empresas que atuam na indústria de transformação no âmbito do objetivo da pesquisa. Os programas SPSS 25 e SPSS AMOS foram usados de forma incremental, e os dados adquiridos foram avaliados e analisados.

Originalidade/Relevância: Nesta pesquisa, os trabalhadores de colarinho branco constituíram nosso grupo de amostragem porque desempenham um papel fundamental na inovação de produtos. Durante a coleta dos dados de análise, as primeiras 500 empresas registradas na Câmara da Indústria de Istambul foram determinadas, e as empresas de manufatura que operam em Istambul constituíram a parte principal do estudo.

Principais resultados: Como resultado da análise, entende-se que a gestão da diversidade e a liderança carismática influenciam positivamente a inovação e o desempenho.

Contribuição teórica/metodológica: Em termos de inovação e desempenho da empresa, o estudo revelou o efeito mediador da liderança carismática ligada à gestão da diversidade.

Contribuições sociais/gerencias: Para que as organizações realizem atividades criativas e inovadoras, é muito importante administrar com eficácia as diferentes ideias e pensamentos dentro das organizações. $\mathrm{Na}$ verdade, a liderança carismática afeta positivamente os funcionários, ajudando-os a ter um melhor desempenho. Portanto, os funcionários devem estar ativamente envolvidos para realizar a inovação com sucesso.

Palavras-chave: Gestão da diversidade, Liderança carismática, Velocidade da inovação, Desempenho da inovação, Desempenho da empresa.

\section{Resumen}

Objetivo del estudio: El propósito de este estudio fue analizar las relaciones entre las variables de gestión de la diversidad, liderazgo carismático, velocidad de innovación, desempeño en innovación y desempeño de la empresa.

Metodología/enfoque: Se realizó un estudio de encuesta con 427 empleados (tanto técnicos como ingenieros) que trabajan en empresas que operan en la industria manufacturera en el ámbito del propósito de la investigación. Los programas SPSS 25 y SPSS AMOS se utilizaron de forma incremental y los datos adquiridos se evaluaron y analizaron.

Originalidad/relevancia: En esta investigación, los empleados administrativos constituyeron nuestro grupo de muestreo porque juegan un papel clave en la innovación de productos. Al recopilar los datos del análisis, se determinaron las primeras 500 empresas registradas en la Cámara de Industria de Estambul, y las empresas de fabricación que operan en Estambul constituyeron la parte principal del estudio.

Principales resultados: Como resultado del análisis, se entiende que la gestión de la diversidad y el liderazgo carismático tienen una influencia positiva en la innovación y el desempeño.

Contribución teórica/metodológica: En términos de innovación y desempeño de la empresa, el estudio reveló el efecto mediador del liderazgo carismático vinculado a la gestión de la diversidad.

Contribuciones sociales/de gestión: Para que las organizaciones lleven a cabo actividades creativas e innovadoras, es muy importante gestionar eficazmente las diferentes ideas y pensamientos dentro de las organizaciones. De hecho, el liderazgo carismático afecta positivamente a los empleados, ayudándolos a desempeñarse mejor. Por lo tanto, los empleados deben participar activamente para llevar a cabo con éxito la innovación.

Palabras-clave: Gestión de la Diversidad, Liderazgo Carismático, Velocidad de Innovación, Desempeño en Innovación, Desempeño de la Empresa. 


\section{Introduction}

Leadership studies first began with the goal of researching the characteristics or personal qualities of leaders in the early 20th century (Reave, 2005). And, social scientists and sociologists have continued their research on charismatic leadership since the middle of the 20th century. The concept of charisma has traditionally been deemed only appropriate for the upper-level figures of political, military, religious, or social movements. But within the academic arena, sociology and social science researchers of charisma have long been interested in kings, presidents, and the leaders of great social and religious movements (Willner, 1984). For years, it was thought that the concept of charisma was not a concept that suited lower-level managers and only charismatic leaders could be found at the upper levels of organizations (Abbasiyannejad et al., 2015). Despite this, it is now understood that charismatic leadership can be found at all levels of an organization (Shamir, 1995). Weber defined charismatic leadership as a person outfitted with unique and extraordinary qualifications who emerges as a result of a social crisis in society, offers radical solutions to crises, and is believed by observers to have extraordinary powers (Grabo et al., 2017). If these characteristics of the charismatic leader positively affect the employees, the leader's organization is likely to be successful in innovation and performance. Therefore, it is important for the organization to be able to manage and cultivate different ideas for leading-edge activities. In this case, diversity management comes to the fore. Research that discussed cultural and demographic differences from an organizational perspective began in the 1960s, and it is thought that the most striking development on the research of labor-force diversity management (from the 1960s until today) was the research on labor-force structure in America (Joshi \& Roh, 2009). In general, labor force diversity expresses the demographic, psychological, and organizational diversity that all employees who emerge in any department or unit of an organization possess. The term diversity is used to express all dimensions in which employees differ in their role, function, and personality (Hicks-Clarke \& Iles, 2000). A charismatic leader, while conveying her or his emotions and thoughts to surrounding people, must also be able to know what others want. Similarly, charismatic leaders must have the requirement that she or he has an effective accumulation of knowledge (Ertan-Kantos, 2011), and the energy and excitement to solve problems. By helping employees work in a more determined manner by conveying their energy and excitement to others, working individuals connect their success not just to themselves but to the leader who motivates them (Keklik, 2012). 
In the literature of management and organization, the subject of human resources and its sustainable value comes to the fore as a tool to recruit and optimize the capacity, skill, originality and creativity of individuals within an organization. Human resources focuses on the subjects of human orientation, work ethics, and culture and can help expand on unique differences included within organizations that are discussed in the context of multiculturalism (Friedman, 2002). Consequently, the issues of diversity and diversity management constitute an important agenda not only for practitioners who are looking to benefit by effectively managing workforce diversity but also for scientists who research how differences should be handled at a theoretical level. The importance of managing differences in organizations without these distinctions turning into conflict involves effective planning that is in harmony with organizational goals. Nowadays, adaptation to change and competition for businesses can only be achieved by valuing human capital and investing. For this reason, it becomes strategically important to ensure the active and decisive handling of manpower with differing characteristics. Both the development and success of an organization and the efficiency and loyalty of the employees is realized by doing more than the duties assigned. Therefore, leadership behaviors are also important for employees. In research, the employees working in the manufacturing industry, one of the areas where different ideas and thoughts are concentrated, constitute the sample mass. It is aimed to contribute to the studies on workers in terms of innovative and creative activities. The effects of diversity management and charismatic leadership on innovation speed, innovation performance, and company performance, are incredibly important for manufacturing companies today and are studied in the scope of the research model.

\section{Literature review}

\subsection{Diversity management}

Management of differences involves the use of processes and strategies that will help turn the differences between people into an advantage rather than a cost for an organization (Demir, 2011). Indeed, diversity management is a process that supports the differences that add increased value to planning, organization, managing, and organizational performance (Hubbard, 2004; Egerova et al. 2013). Diversity management evaluates sustainability and controllability as a process, and in this process, the requirement of providing value to diversity and at the same time bring organizational homogeneity to control diversity (Buckingham, 2010). Diversity management involves extracting the benefits of differences, just as it takes advantage of applications created in order to evaluate the differences of employees in a long- 
term process and in line with organizational goals (Bean et al., 2001). Conversely, the negativity of the approach is that it can complicate the natural welcoming and acceptance of differences. In fact, the negative perspective on differences could constitute a significant obstacle for evaluation (Franken, 2015). Diversity is an important factor in increasing an organization's problem-solving capacity, producing new ideas and alternative solutions, opening new markets, better serving different customer groups, ensuring competitive advantages for organizations on topics of corporate image and marketing, and increasing organizational productivity and effectiveness (Rijamampianina \& Carmichael, 2005). Moreover, Gebert et al. (2006) explains in detail how diversity management has an effect on innovation in their research. Diversity, as a competitive weapon, does not mean that individuals compete with one another and battle within the organization (Villamil, 2007). In fact, employees' competing with one another are expressing each differences, and thus, action through collective consciousness to realize the goal of the organization can be realized. In this regard, the existence of differences should be considered at organizations, but how differences will be managed is the key (Selome, 2008). Should differences be managed ineffectively, it will become unavoidable that a series of problems will emerge and become an obstructive factor in the realization of organizational goals (Güleş, 2012). Indeed, different employees integrated within the shared goals of an organization depend on the extent to which they can foster discussion (Podsiadlowski et al., 2013). For this reason, the importance of the effect of the mediation variable for diversity management is analyzed in the scope of the research model.

\subsection{Charismatic leadership}

Published in 1988, Conger and Kanungo first produced the charismatic leadership theory in 1987, and they made recommendations regarding how charisma affected leaders (at businesses and organizations) and the emergence of charismatic leadership (Conger \& Hunt, 1999). Charisma, just as other leadership types, should be viewed as an attribution made by followers who observe the behaviors of a leader at an organization (Vlachos et al., 2013). Charismatic leadership theories underlie multiple facets of both leaders and their followers: emotional loyalty to the leader, the emotional and motivational adaptation of followers, the strengthening of the desires of followers with respect for the mission, the values and internal motivations of the followers, and the esteem, confidence, and reliance of the followers in the leader (Seong \& Hong, 2018). The leadership behaviors that the charismatic theories specify are distinct from previous organizational leader behaviors. Previous theories have discussed the 
behaviors of leaders in the context of leader-follower exchange, such as providing guidance with support and strengthening behaviors (Conger, 2011). The new leadership theories place symbolic importance on multiple aspects: the behaviors of the leader, visionary and inspiring messages, nonverbal communication, the attractiveness of ideological values, the intellectual stimulation of the followers, the confidence of the leaders and followers, and the performance and sacrifice the leader expects from the followers (Zehir et al., 2011). This leadership style gains meaning for the work by integrating the organization and the work in line with morals, objectives, and loyalty (Shamir et al., 1993). In a charismatic leader, there are a general series of characteristics including high self-confidence, dominance, and powerfully embracing her or his own beliefs (Arıkan 2001). Weber defined deviant and innovative characteristics for the concept of charismatic leadership, viewing charisma as sanctity and connecting charisma to the regulatory skills or sample character of individuals (Weber, 1968). Charismatic leaders, in order to quickly achieve goals, strive to make more willing employees by increasing their courage and showing them that they believe and have confidence in them (House \& Howell, 1992). Diversity management is one of the most effective solutions that businesses can use to be innovative. However, the way to be successful in diversity management is also about the leadership feature. Raza and Tariq (2016) investigated the mediation effect of trust on leadership, and found that diversity management positively affected trust in leadership. This situation has created an assumption in terms of how it will positively affect charismatic leadership, and the mediation variable effect of charismatic leadership was investigated by establishing a hypothesis based on this assumption. At the same time, it is accepted that successful leadership develops innovative and creative activities, particularly when different ideas and thoughts are well managed. So, the relationship between the variables and the findings provides for diversity management in the organization, in addition to how an innovative understanding is influential, all of which are analyzed in the scope of the research model. For this reason, how diversity management affects the charismatic leader is examined.

H1: Diversity management has a significantly positive effect on charismatic leadership.

\subsection{Innovation speed}

Innovation expresses the tendency of a company to be interested in and support new ideas: new products, services, or technological processes with experiments and creative processes (Lumpkin \& Dess, 1996). The existing literature offers various means for classifying innovation, including definite and indefinite, increasing and radical, and technical and 
administrative issues (Soto-Acosta et al. 2016). However, perhaps the most general classification is technological innovation in contrast to innovation in the product market. And, because innovation creates an amount of uncertainty in new ventures, there are studies that focus on the relationship between innovation and the speed of innovation (Schoonhoven et al., 1990). Schoonhoven et al. (1990) claim that however innovative the first product of a new development is, more information must be created or synthesized, and that this leads to longer waiting times in product deliveries. The speed of innovation is an important concept in the literature for new product development, and it demonstrates organizational efficiency in the processes of new product development, in addition to the talents of companies in releasing new products to the market (Kessler \& Bierly, 2002). The constant decrease in the lengths of the life cycle for products has made the speed of innovation into a tool with which they can increase a very valuable resource of the organization as well as the competitive advantages of companies (Vesey, 1991). Companies aim to adapt to the shortening product life cycle and to the rapidly changing environment by including the time perspective when adopting the motto "the highest value for the lowest cost in the lowest amount of time" for competitive advantage creation (Chen et al., 2010). Based on this, more research emerges that focuses on understanding the priorities and outcomes of innovation speed in areas like business strategy, marketing, and new product development. Kessler and Chakrabarti (1996) present a theoretical framework that determines how the speed of innovation can be affected by both strategic orientation factors and organizational talent factors. Additionally, they theorized how this can influence development cost, product quality, and ultimately the success of the project. Companies can create an advantage of time by initially using quicker monitoring strategies and by swiftly adapting to market needs in competitive and dynamic environments (Eisenhardt \& Tabrizi, 1995). For this reason, the research studied how diversity management and a charismatic leadership style affected the variable of innovation speed in organizations.

H2: Diversity management has a significantly positive effect on innovation speed.

H5: Charismatic leadership has a significantly positive effect on innovation speed.

H8: Charismatic leadership influences the mediation variable in the relationship between diversity management and innovation speed.

\subsection{Innovation performance}

Innovation performance relates to how innovation affects the performance of the business (Löfsten, 2014). It also aims to determine the effect of innovation on the 
competitiveness of the business (Necadova \& Scholleova, 2012). This type of performance can include innovations that businesses have made meaning that innovations businesses have offered the potential to realize as much as concrete outputs (Jiménez-Jiménez \& Sanz-Valle, 2011). But, it is necessary to state that it is quite difficult to measure the drafts and other innovative ideas for designs that must be accepted concretely against other assets (such as patents and intellectual-industrial rights that appear as concrete outputs). Therefore, as Kivimäki et al. (2000) stated, innovation performance must be discussed as perceived innovation effectiveness and patent statistics. The important, striking point here is the requirement of innovation performance to be expressed as new and concrete values that reflect on the balance sheets of the business (Alegre \& Chiva, 2013). Businesses in today's business world and markets must use their innovative strength to be able to maintain their existence and always be one step ahead of their competitors (Chen \& Huang, 2009). Businesses that carry themselves forward by using their innovative strength and try to surpass competitors by quickly promoting new products gain value and are favored in the market (Samur, 2011). New services must be regarded with the frequency of new products and services that the company releases. Also, new services should work in alignment with new process systems that the company promotes or releases in order to be able to measure the strength of a business' innovative performance (Prajogo \& Ahmed, 2006). Organizations that produce innovation follow the steps of idea development in the process of innovation, project description, design and development, marketing, and the task of meeting commercial value of innovation (Rangus \& Slavec, 2017). Developed innovation performance in the rapidly changing and competitive global environment of today will provide great benefits to businesses (Lin et al. 2013). These benefits will primarily enable businesses to increase performance and their competitive strength, and in fact, is the reason to examine the effect of diversity management and charismatic leadership on innovation performance. A charismatic leader sets high performance goals for the employees and imposes these goals on their employees. In this way, the charismatic leader motivates his followers to be innovative and creative against organizational and environmental barriers. For this reason, the charismatic leader has a high probability of achieving positive results in both innovative activities and employee performance (Conger et al., 2000). Additionally, Paulsen et al. (2009) and Michaelis et al. (2009) indicate that charismatic leadership has a positive effect on innovation. There are studies supporting the research model, stating that the difference of management positively affects the performance of the employees and the organization if the management is handled correctly. In 2005, the study by Bassett-Jones explained that diversity 
management has a positive effect on creativity and innovation. For this reason, the effects of diversity management and charismatic characteristics of leadership styles on innovation performance are researched.

H3: Diversity management has a significantly positive effect on innovation performance.

H6: Charismatic leadership has a significantly positive effect on innovation performance.

H9: Charismatic leadership influences the mediation variable in the relationship between diversity management and innovation performance.

\subsection{Company performance}

The general performance of a business is evaluated with a single measurement method because it possesses a multidimensional structural property. Carton and Hofer (2006) evaluated the dimensions that must be discussed for the measurement of organizational performance and mentioned these dimensions. In addition, values that include some organizational growth indicators including the profitability dimension, market share, growth dimension, and increase in the rate of sales are the criteria of growth: the ability of a business to resolve cash-flow problems during times of potential financial struggles, as an example. In fact, the performance measurements aimed at the market are related to the added value elements that the market provides for the business (Prajogo \& Ahmed, 2007). Based on this, the performance of a business will advance at the right scale with the functionality of various departments of the business. Therefore, the competencies that departments possess have rather high importance in the occurrence of the integrated organizational performance of the business. Conversely, the study that Venkatraman and Ramanujam conducted in 1986 concluded that business performance could be measured in the form of layers. In other words, there are layers of financial economic performance in which the core financial dimension of the business is found, and at that point, the financial dimension is discussed as to whether the financial goals of the business could materialize (Deshpandé \& Farley, 2004). There is a layer more broadly discussed that includes the financial operational performance meaning the business performance that covers the financial layer (Gunday et al., 2011). At this level are concepts, such as the business' market share, product array and quality, market effectiveness, technological infrastructure, network establishment skill, product and process innovations, production quality, brand value, employee loyalty and satisfaction, and customer satisfaction 
(Prajogo, 2016). In the study conducted by Pitts (2009), diversity management has a positive effect on the performance of the employees supported by the study conducted by Choi and Rainey (2010) that explains how diversity management has a positive effect on the performance of the organization. Therefore, an organization's ability to manage the differences of their employees and its effect on leadership styles can reflect on a company's performance. The research model aimed to study these effects.

H4: Diversity management has a significantly positive effect on company performance.

H7: Charismatic leadership has a significantly positive effect on company performance.

H10: Charismatic leadership influences the mediation variable in the relationship between diversity management and company performance.

\section{Methodology}

This research aims to determine the effects of the relationships between the independent variables of diversity management, the mediation variable of charismatic leadership, and the dependent variables of innovation speed, innovation performance, financial performance, and company performance (the aforementioned based on a literature review of white-collar workers employed at companies operating in the manufacturing sector). White-collar workers constituted our sampling group because they play a key role in product innovation. While gathering the analysis data, manufacturing companies operating in Istanbul constituted the main part of the study. The first 500 companies registered in Istanbul Chamber of Industry were determined, and a survey was collected. The data of the study was sent to the e-mail addresses of white collar employees in all these companies in the form of an online survey, and participation in the survey was provided on a voluntary basis. A total of 1856 white-collar employees were identified from 500 existing companies. 454 of them (24\%) returned the data, and it was included in the analysis since the sample size was deemed sufficient. At the first stage of data entry, it was seen that 27 questionnaires were not properly filled, so these questionnaires were removed from the data set. A total of 427 questionnaires were analyzed. 427 employees employed at different departments responded to our survey in accordance with the criteria, and a total of 248 male and 179 female white-collar workers responded to our survey. Of the participants, $36.7 \%$ were in the $30-40$ age group, $49.7 \%$ were in the $41-50$ age group, and $13.6 \%$ were above the age of 51 . Of the employees who responded to the survey, $76 \%$ were university graduates, $17 \%$ had master's degrees, and $7 \%$ had $\mathrm{PhDs}$. 
Common Method Variance (CMV) can have an impact on structural results and therefore needs to be checked. The CMV may lead to erroneous conclusions about the relationships between the factors by inflating or deflating the variance (Craighead et al., 2011). Anonymity was provided to avoid the Common Method Variance problem in the scale, and answers were given within the necessary time. In the first examination, the single factor structure explained the percentage of the desired situation in the data obtained. Harman's single factor method was also used to test the presence of CVM in the scale. In this test, all statements are fixed to only one factor structure. When the scale, which normally has a 5-factor structure, is fixed to the first factor with the Harman single-factor test, the first factor explained only 35.723 percent of the total variance. If this value is below the threshold value of 0.50 , it indicates that there is no CVM problem for the data set. Before the full use of the scale was carried out, a pre-test of 40 people was made and some items were removed from the scale since it was seen that they were not understood.

\subsection{Scales}

Accordingly, our research purpose was to evaluate and analyze manufacturing firms in terms of both leadership as well as innovation and performance. The survey questions represented 5 variables. The questionnaire questions were first translated into Turkish, then corrections were made in the sentences in order to make it clearer and more understandable in accordance with the Turkish language. The questionnaire questions were translated into English-Turkish in the first stage. Therefore, when the Turkish-English translation is made while writing the article, it looks different from the original questions. The diversity management scale: referenced important studies were considered in many studies in the literature review, Selome (2008), Villamil (2007), Buckingham (2010), Bean et al. (2001), Podsiadlowski et al. (2013). Charismatic Leadership in the measurement in the sample group; Vlachos et al. (2013), Conger \& Kanungo (1994), Zehir et al. (2011), Seong \& Hong (2018). Innovation Speed; Allocca \& Kessler (2006), Carbonell \& Rodríguez-Escudero (2009), Carbonell \& Rodriguez Escudero (2010), Shan et al. (2016). Innovation Performance; Jiménez-Jiménez \& Sanz-Valle (2011), Rangus \& Slavec (2017), Prajogo \& Ahmed (2006), Chen \& Huang (2009), Chen et al. (2009). In the scale in which Company performance is evaluated, the scales are used in Deshpandé \& Farley's studies (2004), Zahra \& Covin (1993), Gunday et al. (2011), Prajogo (2016), as well as Prajogo \& Ahmed (2007). The statements were 
taken from the publications and converted to Turkish in the same way. A 5-point Likert scale that ranged from "I definitely do not agree" to "I definitely agree" was also used in the scales.

\subsection{Research framework}

Based on literature review, a research model was implemented for the independent variables of diversity management, the mediation variable of charismatic leadership, and the dependent variables of innovation speed, innovation performance, financial performance, and company performance. The research adopted a quantitative approach because the data were analyzed to determine the relationship between statistical concepts. We used the independent variable or variables to judge the effect on the dependent variable in the quantitative research test (Thomas et al., 2015). The research model is presented in Figure 1.

Figure 1 - Research model

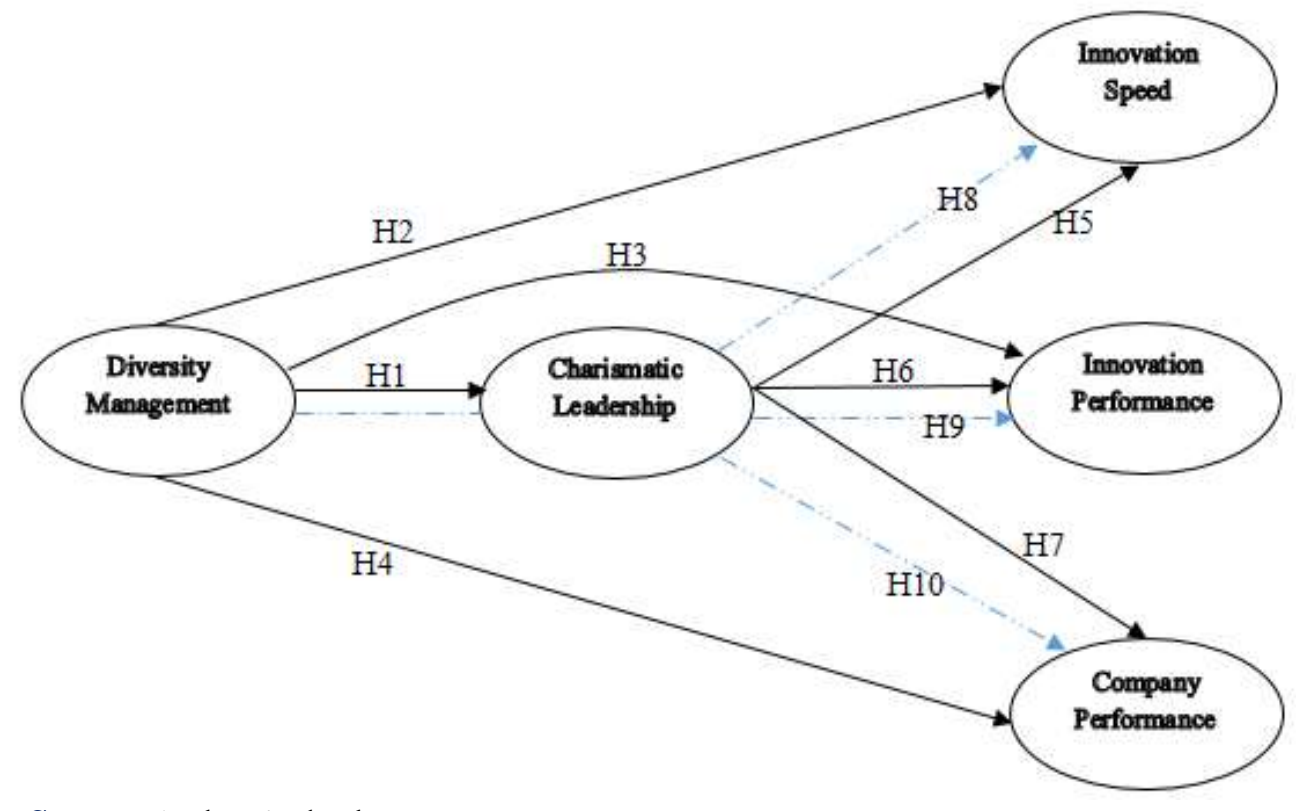

Source: Authors's database.

\section{Analysis}

The study examined whether the given model was supported using an affirmative modelling strategy. For this purpose, a 95-unit pretest was conducted. The structure, order, and number of the questions in this scale were determined. Questions that had the possibility of being misunderstood were made clearer. There were 60 scales on the survey presented during the pretest phase, and 10 expressions for which suitable factor loads did not form as a result of the preliminary test and that were misunderstood or had the potential to be misunderstood were 
removed. Additionally, a structure was supported by the literature with five factors comprising 50 expressions. The scale was administered to 454 personnel over production, and 27 surveys thought not to have been answered well or that could have affected the reliability of the scale were removed from the data analysis. As a result of the analysis, a scale comprising 50 statements was produced, and it was performed for 427 participants. 22 statements in the scale were excluded from the analysis because they did not show the appropriate factor load, and analyzes were performed on 28 statements.

The hypotheses in the research model will be tested with the acquired data. The IBM SPSS 25 and IBM SPSS AMOS programs were used incrementally in the analysis. The factor loads as a result of the Factor analysis, were conducted with SPSS (F. Score), Factor Numbers (F.N.), and standardized values calculated with the AMOS program for these questions are presented in Table 1, which includes which questions that are found under each factor. When the multiple normalcy test was administered for each statement, it was seen that all the statements had normal distribution. For this reason, Structural Equation Modelling was used in the analysis and explanations of the models. 
Table 1 - Confirmatory factor analysis results

\begin{tabular}{|c|c|c|c|c|}
\hline & F.N. & F Score & T Value & p-value \\
\hline DM1. Discussions regarding differences are valued. & 1 & 0.898 & 15.61 & 0.000 \\
\hline DM2. Differences are not considered a problem. & 1 & 0.870 & 15.76 & 0.000 \\
\hline M3. Differences are not perceived as a threat to the company. & 1 & 0.848 & 17.90 & 0.000 \\
\hline $\begin{array}{l}\text { DM4. It is considered reasonable to openly express ideas } \\
\text { regarding differences. }\end{array}$ & 1 & 0.833 & 17.99 & 0.000 \\
\hline M5. The differences between employees are not ignored. & 1 & 0.832 & 18.28 & 0.000 \\
\hline M6.There is a positive ou & 1 & & & 0.000 \\
\hline $\begin{array}{l}\text { DM7. The open expression of feelings and ideas relating to } \\
\text { differences is welcome. }\end{array}$ & 1 & 0.807 & 19.68 & 0.000 \\
\hline M8.Differences are seen as a source of new ideas. & 1 & 0.752 & 19.10 & 0.000 \\
\hline $\begin{array}{l}\text { DM9. Employees with different views and thoughts are used } \\
\text { on many topics. }\end{array}$ & 1 & 0.668 & 20.52 & 0.000 \\
\hline $\begin{array}{l}\text { ronment is created in which employees can } \\
\text { ir ideas regarding differences. }\end{array}$ & 1 & 0.612 & 19.28 & 0.000 \\
\hline & 2 & 0.902 & 18.50 & 0.000 \\
\hline $\begin{array}{l}\text { CL2. The leaders of our company appoint people based on their } \\
\text { own skills and talents. }\end{array}$ & 2 & 0.819 & 18.35 & 0.000 \\
\hline $\begin{array}{l}\text { L3. The leaders of our company are united and loyal to one } \\
\text { other. }\end{array}$ & 2 & 0.757 & 20.56 & 0.000 \\
\hline e leaders of our company have good qualities. & 2 & 0.679 & 11.60 & 0.000 \\
\hline $\begin{array}{l}\text { leaders of our company are encouraging on the topic } \\
\text { ting. }\end{array}$ & 2 & 0.665 & 11.82 & 0.000 \\
\hline $\begin{array}{l}\text { e leaders of our company are encouraging on the topic } \\
\text { risks. }\end{array}$ & 2 & 0.607 & 17.80 & 0.000 \\
\hline $\begin{array}{l}\text { he company where I work, there is employee } \\
\text { on. }\end{array}$ & 3 & 0.867 & 20.01 & 0.000 \\
\hline $\begin{array}{l}\text { company where I work, general company } \\
\text { is comparetive to our competitors }\end{array}$ & 3 & 0.828 & 17.96 & 0.000 \\
\hline $\begin{array}{l}\text { apany where I work, profitability has increased } \\
\text { years. }\end{array}$ & 3 & 0.905 & 16.12 & 0.000 \\
\hline where I work, the market share has & 3 & 0.879 & 20.90 & 0.000 \\
\hline $\begin{array}{l}\text { CP5. At the company where I work, our sales volume has } \\
\text { increased in the past two years. }\end{array}$ & 3 & 0.754 & 18.21 & 0.000 \\
\hline $\begin{array}{l}\text { company where I work, our costs have fallen in the } \\
\text { ars. }\end{array}$ & 3 & 0.607 & 17.90 & 0.000 \\
\hline $\begin{array}{l}\text { IS1. Our innovation speed as compared to large competitors } \\
\text { developing similarly is very good. }\end{array}$ & 4 & 0.920 & 17.54 & 0.000 \\
\hline $\begin{array}{l}\text { IS2. Our company is known for its innovation speed in our } \\
\text { sector. }\end{array}$ & 4 & 0.838 & 15.12 & 0.000 \\
\hline $\begin{array}{l}\text { IS3. According to the specified schedule, the "full-time } \\
\text { performance", which is our development, is very good. }\end{array}$ & 4 & 0.643 & 14.72 & 0.000 \\
\hline $\begin{array}{l}\text { npetitors in terms of new products / } \\
\text { narket. }\end{array}$ & 5 & 0.793 & 16.70 & 0.000 \\
\hline $\begin{array}{l}\text { IP2. In the past } 3 \text { years, our company exhibited better } \\
\text { performance than its competitors by paying attention to hours, } \\
\text { people, teams, and training with efforts spent to develop new } \\
\text { products/services. }\end{array}$ & 5 & 0.782 & 19.31 & 0.000 \\
\hline $\begin{array}{l}\text { IP3. In the past } 3 \text { years, our company exhibited better } \\
\text { performance than its competitors regarding leadership in } \\
\text { promoting new products/services. }\end{array}$ & 5 & 0.777 & 19.15 & 0.000 \\
\hline
\end{tabular}

Source: Authors's database. 
The number-1 expressions found in Table 1 constitute the factor of diversity management (DM), the number-2 expressions constitute the factor of Charismatic Leadership (CL), the number-3 statements constitute the factor of firm performance (FRP), the number-4 statements constitute the factor of innovation speed (IS), and the number-5 statements constitute the factor of innovation performance (IP). Table 1 presents the factor loading values specified for each factor created by the expressions, the standardized AMOS results, the t-test results for the observed variables, and the p-values that show whether these test results were meaningful. According to these results, the analysis results for all the observed values are meaningful (all p-values<0.001). Variance Inflation Factor (VIF) values for all expressions in the analysis were between 1.228 and 3.798 . VIF values less than 5 indicate that there is no multicollinearity problem for the data set. The Kaiser Mayer Olkin (KMO) and Bartlett's Test value was found to be 0.942 for the Factor analysis conducted in the SPSS 25 program. A KMO value of greater than 90 is interpreted as an "excellent" result (Tavşanc1l, 2002). This value demonstrates that the data are suitable for analysis, while the fact that the sig. value acquired as a result of Bartlett's Test is 0.000 ( $\mathrm{sig}<0.05)$, demonstrating that the data are suitable for a factor analysis, that the acquired Chi-Square value is meaningful, and that the data come from a multivariable normal distribution. Considering the Total Variance Explained table in the factor analysis, it is seen that a 5-factor structure accounts for $69.17 \%$ of the structure wishing to be researched. An affirmative factor analysis was conducted in the AMOS program for the model. Table 2 provides the consistency indices acquired from the models. By examining the values in the table, it can be seen that the model has good consistency values for all the consistency wellness values. The relationship analysis, effect analysis, and mediation variable analysis conducted after determining that the current expressions were suitable for the model.

Table 2 - Goodness fit index value and reference values

\begin{tabular}{lll}
\hline Goodness of Fit Statistics & Value & Reference Values \\
\hline Chi-Square $\left(\chi^{2}\right)$ & 1016.49 & $\left(\chi^{2}\right) / \mathrm{Df}<5$ good fit OR \\
Degrees of Freedom & 390 & $\left(\chi^{2}\right) / \mathrm{Df}<3$ good fit $(1016.49 / 390=2.61)$ \\
& 0.063 & $\begin{array}{l}\text { RMSEA }<0.05 \text { perfect fit } \\
\text { RMSEA }<0.08 \text { good fit }\end{array}$ \\
Root Mean Square Error of Approximation(RMSEA) & & $\begin{array}{l}0.08=<\text { RMSEA }<0.10 \text { mediocre fit } \\
\end{array}$ \\
& & $0.10=>$ RMSEA poor fit \\
Root Mean Square Residual (RMR) & 0.041 & RMR $<0.05$ \\
Normed Fit Index (NFI) & 0.97 & NFI $>0.95$ good fit \\
Non-Normed Fit Index (NNFI) & 0.98 & NNFI $>0.95$ good fit \\
Comparative Fit Index (CFI) & 0.98 & CFI $>0.95$ good fit \\
Relative Fit Index (RFI) & 0.96 & $0<R F I<1$ Close to 1 better fit \\
Goodness of Fit Index (GFI) & 0.85 & GFI $>0.85$ \\
\hline
\end{tabular}

Source: Authors's database, *Jöreskog and Sörbom (1993), Kline (2005), Schermelleh-Engel et al., (2003), Erkorkmaz et al., (2013), and Hooper et al., (2008). 
The average between the questions produced a relationship with the reliability analysis (listed in the section after the analysis). The literature accepts measurements for the Cronbach Alpha coefficient of 0.50 that Nunnally (1978) determined and higher as adequate (Nunnally, 1978; Hair et al., 2000). Table 3 provides the reliability coefficients acquired for each factor, the variance sizes that the factors explain, the KMO values for all the factors, and the results of Bartlett's Test.

Table 3 - Factor structures, reliability values and factor statistics

\begin{tabular}{lccccc}
\multicolumn{1}{c}{ Dimensions/Factors } & N of Items & $\begin{array}{c}\text { Cronbach's } \\
\text { Alpha }\end{array}$ & $\begin{array}{c}\text { Variance } \\
\text { Explained }\end{array}$ & $\begin{array}{c}\text { Kaiser- } \\
\text { Meyer-Olkin } \\
\text { Statistics }\end{array}$ & $\begin{array}{c}\text { P value of } \\
\text { Bartlett's Test } \\
\text { of } \\
\text { Sphericity }\end{array}$ \\
\hline $\begin{array}{l}\text { DM (Diversity } \\
\text { Management) }\end{array}$ & 10 & .941 & .654 & .945 & .000 \\
CL (Charismatic & 6 & .857 & .604 & .864 & .000 \\
$\begin{array}{l}\text { Leadership) } \\
\text { IS (Innovation Speed) }\end{array}$ & 3 & .781 & .700 & .670 & .000 \\
IP (Innovation Performance) & 3 & .845 & .764 & .724 & .000 \\
CP (Company Performance) & 6 & .866 & .722 & .809 & .000 \\
\hline
\end{tabular}

Source: Authors's database.

According to the calculated factor reliability coefficients, all the acquired values were greater than 0.50 . The fact that these values were high means that more reliable results were obtained. The results of the factor analysis also demonstrate that the data are consistent for the factor analysis. The explained variance values show that the factor-explanation values for the factor statements were greater than 0.60 for all the factors. The correlation coefficient provides the degree of the relationship between the data (Landau et al., 2004). Table 4 provides the calculations for the factors' relationship degrees between them. After determining the consistency of the data, we passed to the test stage of the hypotheses.

Table 4 - Correlations

\begin{tabular}{lcccc}
\hline & CL & IP & IS & CP \\
\hline DM & $.511^{* *}$ & $.523^{* *}$ & $.443^{* *}$ & $.511^{* *}$ \\
CL & 1 & $.544^{* *}$ & $.473^{* *}$ & $.436^{* *}$ \\
IP & & 1 & $.514^{* *}$ & $.553^{* *}$ \\
IS & & & 1 & $.547^{* *}$ \\
\hline Legend: DM (Diversity & Management), & CL & (Charismatic \\
Leadership), IS (Innovation Speed), & IP & (Innovation \\
$\begin{array}{l}\text { Performance), CP (Company Performance). } \\
\text { Source: Authors's database. }\end{array}$ & & & \\
\end{tabular}


Those with double-stars over the correlation coefficients are factors with significant correlation at the importance level of $1 \%$. All the values were found to be meaningful in the hypothesis test given so that $\beta$, the correlation coefficient, was not equal to zero. All sig. values were smaller than 0.01. At this stage, the hypotheses given in Table 5 were tested with the SPSS program, and Table 5 shows the results of the hypotheses.

Table 5 - Linear regression results

\begin{tabular}{clccccc}
\hline H & $\begin{array}{c}\text { Independent Variables/Dependent } \\
\text { Variables }\end{array}$ & $\begin{array}{c}\text { Std. } \\
\boldsymbol{\beta}\end{array}$ & $\begin{array}{c}\mathbf{p -} \\
\text { value }\end{array}$ & $\begin{array}{c}\text { Adj. R } \\
\text { Square }\end{array}$ & F Value & $\begin{array}{c}\text { Reject/ } \\
\text { Accept }\end{array}$ \\
\hline H1 & DM has a significantly positive effect on CL. & .511 & .000 & .260 & 140.895 & Accept \\
H2 & DM has a significantly positive effect on IS. & .443 & .000 & .194 & 97.118 & Accept \\
H3 & DM has a significantly positive effect on IP. & .523 & .000 & .272 & 150.238 & Accept \\
H4 & DM has a significantly positive effect on CP. & .508 & .000 & .256 & 138.182 & Accept \\
H5 & CL has a significantly positive effect on IS. & .473 & .000 & .222 & 114.682 & Accept \\
H6 & CL has a significantly positive effect on IP. & .544 & .000 & .294 & 167.490 & Accept \\
H7 & CL has a significantly positive effect on CP. & .428 & .000 & .181 & 89.066 & Accept \\
\hline
\end{tabular}

Legend: DM (Diversity Management), CL (Charismatic Leadership), IS (Innovation Speed), IP (Innovation Performance), CP (Company Performance).

Source: Authors's database.

Table 5 provided the linear regression results acquired according to the hypotheses. Table 5 shows the Sig. values calculated for the R-square values, which demonstrate how much the independent variable explains for the change in the dependent variable and for the F Values that shows whether the established model is, as a whole, meaningful. According to the acquired results, all the hypotheses were accepted, because the sig. values were smaller than 0.01 .

H8: CL influences the mediation variable in the relationship between DM and IS.

H9: CL influences the mediation variable in the relationship between DM and IP.

H10: CL influences the mediation variable in the relationship between DM and CP.

The AMOS program was used to analyze the mediation variable effect. After determining the exogenous and endogenous variables, processes for the analysis model were conducted for the H8-H10 hypotheses. Table 6 provided the acquired results.

Table 6 - Mediation variable analysis results

\begin{tabular}{cccccc}
\hline H & $\begin{array}{c}\text { Endogenous } \\
\text { Variables }\end{array}$ & $\begin{array}{c}\text { Exogenous } \\
\text { Variable }\end{array}$ & Std. $\boldsymbol{\beta}$ & p-value & Reject/Accept \\
\hline H8 & DM & CL-IS & .272 & .000 & Accept \\
H9 & DM & CL-IP & .332 & .000 & Accept \\
H10 & DM & CL-CP & .391 & .000 & Accept \\
\hline
\end{tabular}

Legend: DM (Diversity Management), CL (Charismatic Leadership), IS (Innovation Speed), IP (Innovation Performance), CP (Company Performance).

Source: Authors's database. 
When reviewing Table 6, it can be seen that all the p-values were meaningful. To discuss the mediation variable effect, the mediation variable must reduce or render meaningless the relationship value standardized in the model. As shown in Table 5, the standardized value between MD-IS in the model was 0.443 , while this relationship fell to 0.272 when CL was added to the model as a mediation variable. When the Table 5 and Table 6 values were compared, it can be seen that CL influences the mediation variable and reduces the previous relationships in all analysis in which CL enters the model as the mediation variable.

\section{Discussion}

Looking at some of the previous studies, Chang (2018) stated in his study that charismatic leadership has a positive effect on unit management innovation. In his research, Van Gool (2019) mentions the positive effect of charismatic leadership on innovative work behavior. In our research, charismatic leadership has both independent and mediation effects on innovation and performance. So, our research showed that charismatic leadership had influence between diversity management, innovation, and company performance. It is specified that charismatic leadership is more influential in situations of stressful crisis or under uncertainty (Bligh \& Kohles, 2010). Charismatic leaders offer a vision or ideas that create the solution to important problems that a group or organization faces; in addition, leaders capture the interest of the employees who trust their extraordinary talents on the topic of managing critical problems. Cox $\operatorname{Jr}(1991)$ is among the names that gained prominence regarding differences at organizations for the academic literature. Cox $\operatorname{Jr}$ (1991) discussed the correlation between an organization's level of competition with that of cultural differences (Miller \& Rowney, 2001). Researchers and practitioners approve of the views of Roosevelt Thomas and specify that the effective management of diversity does not include "making one group more advantageous compared to other groups". This perspective encompasses everyone and is generally supported in many circles (Thomas, 2004). Different management ventures, including special activity programs, policies, and other official processes or efforts, are designed to encourage change in the organizational culture regarding diversity (Wentling \& Nilda, 2000). One of the many goals that diversity management frequently verbalizes is assisting labor force diversity in evaluating, using, and overcoming obstacles like discrimination (Healy et al., 2010). In particular, Roberts and Hauptman (1987) found that technological innovation was positively related to a longer wait time for product promotion at biomedical companies. Additionally, Meyer and Utterback (1995) believe that product innovation negatively affects the speed of new 
product development, because it requires project teams to consider their alternative designs, new development processes, and new marketing channels. As a result of the research, it is clear that diversity management has a positive effect on innovation and performance if supported by effective and positive leadership understanding. However, there are studies that have obtained different results. Homberg and Bui (2013) stated, as a result of their research that diversity variables do not have a significant effect on performance criteria. These findings are deemed plausible when compared with the results of previous meta-analysis conducted by Certo et al. (2006) and Joshi, Liao and Roh (2011), who found effect sizes ranging from small negative to small positive numbers. However, there are studies indicating that organizational performance will be positively affected if diversity management is successfully managed (Ogolla, 2017; Egelan, 2018). Considering that labor diversity has both advantages (such as minority skill and innovation drawing) and disadvantages (such as increasing conflict, additional education expenses, and communication problems), diversity management has an important influence for both employees and institutions. Effective diversity management ensures that organizations utilize the diversity of the labor force and minimize negative outcomes. To ensure benefit from diversity, it must be effectively managed by designing suitable strategies and policies aimed at the complete use of diversity. Since the research is carried out in manufacturing companies and surveys are collected from a certain sample population, there are certain restrictions. Research can only create a certain opinion for manufacturing companies, and it would not be an equitable idea to spread the research results to the general. At the same time, it is of course possible to get different results if the research is done in companies in the service sector (banking, tourism, ready-to-wear stores, telecom companies, etc.). Therefore, it is necessary to be careful in choosing the sector and company in future research.

\section{Conclusions}

Fundamentally, team leaders underneath charismatic leadership act socially and try to create high group performance. The international competition that has emerged, due to the facilitation of demographic change in the labor force and customer composition, as well as access to global markets, has recently brought the subject of diversity management to the agenda for organizational discipline. The supervisory approach deals with human resources as a potential element that can create competitive superiority and focuses on providing organizational gains by managing diversity. With this approach, a transition was experienced from equal employment opportunity with "emotional" tendencies in the relevant literature to an 
approach of diversity management with a managerial tendency (Özbilgin, 2009). Thomas (1990) is remembered as the person who brought forth the concept of diversity management. According to Thomas (1990), diversity management "is to create an environment in which everyone at an organization can add something and reveal her or his entire performance for the goals of the organization". In this sense, diversity management cannot be evaluated as containing or controlling differences. In reality, it is the establishment of managerial structures that will enable the resolution of conflicts and uncertainty emerging from discrimination, along with the creation of positive outputs for the organization as a result of creating a fair and equal working environment for all employees. In this respect, looking at the results of the research, a charismatic leadership mediation variable, which is one of the positive leadership styles, positively affects innovation and performance under variable effects. At the same time, the success achieved in diversity management positively reflects on the creativity activities of the employees, and this situation ensures success in innovation and performance. If there is no success in diversity management, this may lead to negative situations in the organization. So, it is thought that the heterogeneity of human resources will not only increase innovation and creativity but also could lead to conflicts if personal competition cannot be managed (Saruhan \& Y1ld1z, 2009). Along with the contribution and influence of leaders in the success of innovative practices, the business culture and its structure have important influences in the process of being an innovative business. Looking at the results of the research, both diversity management and charismatic leadership positively affect the speed of innovation, innovation performance, and business performance. In other words, positive effects are supported by the hypotheses. A business's ability to maintain their existence and ensure permanent superiority is only possible as a result of having both a creative and innovative organizational structure, in addition to an organizational culture. In future studies in this field, researchers should decide in which sector they should research diversity management. At the same time, we can recommend that they examine diversity management among blue-collar employees instead of white-collar employees since the results of research on blue-collar workers could be interesting. Furthermore, we can foresee that those who want to research diversity management on bluecollar workers will get more useful answers if they perform face-to-face questioning. So, it is very important in which sectors research should be conducted in this field in the future and data should be collected from which employees. However, different modern leadership styles can also be examined through research, and in the future researchers will be able to provide new 
information to the literature if they examine education, culture, and economic development levels as control variables in their research.

\section{References}

Abbasiyannejad, M., Silong, A. D., Ismail, I. A., Othman, J., Wahiza, N., \& Wahat, A. (2015). Charismatic leadership and society. International Research Journal of Social Sciences, 4(1), 68-73.

Alegre, J., \& Chiva, R. (2013). Linking entrepreneurial orientation and firm performance: The role of organizational learning capability and innovation performance. Journal of small business management, 51(4), 491-507.

Allocca, M. A., \& Kessler, E. H. (2006). Innovation speed in small and medium-sized enterprises. Creativity and Innovation Management, 15(3), 279-295.

Arıkan, S., (2001). Liderlik, Yönetim ve Organizasyon, Ankara, Nobel Yayın Dağıtım. Bassett-Jones, N. (2005). The paradox of diversity management, creativity and innovation. Creativity and innovation management, 14(2), 169-175.

Bean, R., Sammartino, A., O'Flynn, J., Lau, K., \& Nicholas, S. (2001). Using diversity climate surveys: A toolkit for diversity management. Programme for the Practice of Diversity Management by Department of Immigration and Multicultural Affairs (DIMA) and Australian Centre for International Business (ACIB).

Bligh, M. C., \& Kohles, J. C. (2010). Charismatic leadership. In J. M. Levine, \& M. A. Hogg (Eds.), Encyclopedia of group processes and intergroup relations. Los Angeles, CA: Sage.

Buckingham, C. D. E. (2010). A case study exploring the impact of managing workplace diversity on diversity awareness and employee job satisfaction. Capella University.

Carbonell, P., \& Rodriguez Escudero, A. I. (2010). The effect of market orientation on innovation speed and new product performance. Journal of Business \& Industrial Marketing, 25(7), 501-513.

Carbonell, P., \& Rodríguez-Escudero, A. I. (2009). Relationships among team's organizational context, innovation speed, and technological uncertainty: An empirical analysis. Journal of Engineering and Technology Management, 26(1-2), 28-45.

Carton, R. B., \& Hofer, C. W. (2006). Measuring organizational performance: Metrics for entrepreneurship and strategic management research. Edward Elgar Publishing.

Certo, S. T., Lester, R. H., Dalton, C. M., \& Dalton, D. R. (2006). Top management teams, strategy and financial performance: A meta-analytic examination. Journal of Management Studies, 43, 813-839.

Chang, Y. Y. (2018). Charismatic leadership in IT firms in Taiwan: an empirical study. Asia Pacific Business Review, 24(1), 53-71. 
Chatman, J. A., Polzer, J. T., Barsade, S. G., \& Neale, M. А. (1998 йил December). Being Different Yet Feeling Similar: The Influence of Demographic Composition and Organizational Culture on Work Processes and Outcomes. Administrative Science Quarterly, 43 (4), 749-780.

Chen, C. J., \& Huang, J. W. (2009). Strategic human resource practices and innovation performance - The mediating role of knowledge management capacity. Journal of business research, 62(1), 104-114.

Chen, J., Damanpour, F., \& Reilly, R.R. (2010). Understanding antecedents of new product development speed: A meta-analysis. Journal of Operations Management, 28(1), 17-33.

Chen, Y. S., Lin, M. J. J., \& Chang, C. H. (2009). The positive effects of relationship learning and absorptive capacity on innovation performance and competitive advantage in industrial markets. Industrial Marketing Management, 38(2), 152-158.

Choi, S., \& Rainey, H. G. (2010). Managing diversity in US federal agencies: Effects of diversity and diversity management on employee perceptions of organizational performance. Public Administration Review, 70(1), 109-121.

Conger, J. A. \& Kanungo, R. N., (1987), Toward a Behavioral Theory of Charismatic Leadership in Organizational Settings, Academy of Management Review, 12 (4), 637-647.

Conger, J. A. (2011). Charismatic leadership. The SAGE handbook of leadership, 86-102.

Conger, J. A., \& Hunt, J. G. (1999). Charismatic and transformational leadership. The Leadership Quarterly, 2(10), 121-127.

Conger, J. A., \& Kanungo, R. N. (1994). Charismatic leadership in organizations: Perceived behavioral attributes and their measurement. Journal of organizational behavior, 15(5), 439-452.

Conger, J. A., Kanungo, R. N., \& Menon, S. T. (2000). Charismatic Leadership and Follower Effects. Journal of Organizational Behavior, 21 (7), 747-767.

Cox Jr, T. (1991). The multicultural organization. Academy of Management Perspectives, 5(2), 34-47.

Craighead, C. W., Ketchen, D. J., Dunn, K. S., \& Hult, G. T. M. (2011). Addressing common method variance: Guidelines for survey research on information technology, operations, and supply chain management. IEEE Transactions on Engineering Management, 58(3), $578-588$.

Demir, Y. (2011). Farklılıkların Yönetimi. Karınca Dergisi. 76 (890).

Deshpandé, R., \& Farley, J. U. (2004). Organizational culture, market orientation, innovativeness, and firm performance: an international research odyssey. International Journal of Research in Marketing, 21(1), 3-22. 
Egelan, A. (2018). Effects of Diversity Management on Organizational Performance: A Case Study of Narok County (Doctoral dissertation, MUA).

Egerova, D., Jiřincová, M., Lančarič, D., \& Savov, R. (2013). Applying the concept of diversity management in organisations in the Czech Republic and the Slovak Republic-a research survey. Technological and Economic Development of Economy, 19(2), 350-366.

Eisenhardt, K.M., \& Tabrizi, B.N. (1995). Accelerating adaptive processes: Product innovation in the global computer industry. Administrative Science Quarterly, 40(1), 84110.

Erkorkmaz, Ü., Etikan, İ., Demir, O., Özdamar, K., \& Sanisoğlu, S. Y. (2013). Doğrulayıc1 faktör analizi ve uyum indeksleri. Turkiye Klinikleri Journal of Medical Sciences, 33(1), 210-223.

Ertan-Kantos, Z. (2011). Leadership in organization metaphors: A conceptual analysis. Journal of Educational Sciences Research, 1(1), 135-158.

Franken, S. (2015). Personal: diversity management. Wiesbaden: Springer Gabler.

Gebert, D., Boerner, S., \& Kearney, E. (2006). Cross-functionality and innovation in new product development teams: A dilemmatic structure and its consequences for the management of diversity. European journal of work and organizational psychology, 15(4), 431-458.

Grabo, A., Spisak, B. R., \& van Vugt, M. (2017). Charisma as signal: An evolutionary perspective on charismatic leadership. The Leadership Quarterly, 28(4), 473-485.

Güleş, H. (2012). Örgütlerde Farklılıkların Yönetimi: Okullara İlişkin Bazı Çıkarımlar. The Journal of Academic Social Science Studies, 5 (8).

Gunday, G., Ulusoy, G., Kilic, K., \& Alpkan, L. (2011). Effects of innovation types on firm performance. International Journal of production economics, 133(2), 662-676.

Hair, J. F., Bush, R. P., \& Ortinau, D. J. (2000). Marketing research: A practical approach for the new millennium. Irwin Professional Publishing.

Healy, G., Kirton, G., \& Noon, M. (2010). Equality, Inequalities and Diversity, Palgrave Macmillan, Basingstoke.

Hicks-Clarke, D., \& Iles, P. (2000). Climate for diversity and its effects on career and organisational attitudes and perceptions. Personnel Review, 29(3), 324-345.

Homberg, F., \& Bui, H. T. (2013). Top management team diversity: a systematic review. Group \& Organization Management, 38(4), 455-479.

Hooper, D., Coughlan, J., \& Mullen, M. (2008). Structural equation modelling: Guidelines for determining model fit. Articles, 2. 
House, R. J., \& Howell, J. M. (1992). Personality and charismatic leadership, The Leadership Quarterly, 3 (2), 81-108.

Hubbard, E. E. (2004). The Manager's Pocket Guide to Diversity Management. Published By: Harward Press. 22 Amherst Road Amherst, U.S. And Canada.

Jiménez-Jiménez, D., \& Sanz-Valle, R. (2011). Innovation, organizational learning, and performance. Journal of business research, 64(4), 408-417.

Jöreskog, K. G., \& Sörbom, D. (1993). LISREL 8: Structural equation modeling with the SIMPLIS command language. Scientific Software International.

Joshi, A., \& Roh, H. (2009). The role of context in work team diversity research: A metaanalytic review. Academy of Management Journal, 52(3), 599-627.

Joshi, A., Liao, H., \& Roh, H. (2011). Bridging domains in workplace demography research: A review and reconceptualization. Journal of Management, 37, 521-552.

Keklik, B. (2012). Sağlık Hizmetlerinde Benimsenen Liderlik Tiplerinin Belirlenmesi: Özel Bir Hastane Örneği. Afyon Kocatepe Üniversitesi İktisadi ve İdari Bilimler Fakültesi Dergisi, 14(1), 73-93.

Kessler, E.H., \& Bierly, P.E. (2002). Is faster really better? An empirical test of the implications of innovation speed. IEEE Transaction Engineering Management, 49(1), 2 12.

Kessler, E.H., \& Chakrabarti, A.K. (1996). Innovation speed: A conceptualmodel of context, antecedents, and outcomes. Academy of Management Review, 21(4), 1143-1191.

Kivimäki, M., Länsisalmi, H., Elovainio, M., Heikkilä, A., Lindström, K., Harisalo, R., ... \& Puolimatka, L. (2000). Communication as a determinant of organizational innovation. $R \& D$ Management, 30(1), 33-42.

Kline, T. (2005). Psychological testing: A practical approach to design and evaluation. Sage.

Landau, D. P., Tsai, S. H., \& Exler, M. (2004). A new approach to Monte Carlo simulations in statistical physics: Wang-Landau sampling. American Journal of Physics, 72(10), 12941302.

Lin, E. S., Hsiao, Y. C., \& Lin, H. L. (2013). Complementarities of R\&D strategies on innovation performance: evidence from Taiwanese manufacturing firms. Technological and Economic Development of Economy, 19(sup1), S134-S156.

Löfsten, H. (2014). Product innovation processes and the trade-off between product innovation performance and business performance. European Journal of Innovation Management.

Lumpkin, G.T., \& Dess, G.G. (1996). Clarifying the entrepreneurial orientation construct and linking it to performance. Academy of Management Review, 135-172. 
Meyer, M. H., \& Utterback, J. M. (1995). Product development cycle time and commercial success. IEEE transactions on engineering management, 42(4), 297-304.

Michaelis, B., Stegmaier, R., \& Sonntag, K. (2009). Affective commitment to change and innovation implementation behavior: The role of charismatic leadership and employees' trust in top management. Journal of Change Management, 9(4), 399-417.

Miller, G. E., \& Rowney, J. I. A. (2001). One step forward, or two steps back? Diversity management and gender in organizational analysis.

Necadova, M., \& Scholleova, H. (2012). Competitiveness and innovation performance of the Czech Republic in international rankings. Research Journal of Economics, Business and ICT, 4.

Nunnally, J. C. (1978). Psychometric Theory: $2 d$ Ed. McGraw-Hill.

Ogolla, D. (2017). Relationship Between Diversity Management Practices and Organization Performance: A Case of Kenya Public Universities in Nairobi County. International Journal of Current Aspects in Human Resource Management, 1(1), 1-17.

Özbilgin, M. F. (2009). Introduction. In M. F. Özbilgin (Ed.), Equality, Diversity and Inclusion at Work: A Research Companion (pp. 1-13). Cheltenham: Edward Elgar Publishing Limited.

Paulsen, N., Maldonado, D., Callan, V. J., \& Ayoko, O. (2009). Charismatic leadership, change and innovation in an R\&D organization. Journal of Organizational Change Management. 22(5), 511-523.

Pitts, D. (2009). Diversity management, job satisfaction, and performance: Evidence from US federal agencies. Public Administration Review, 69(2), 328-338.

Podsiadlowski, A., Gröschke, D., Kogler, M., Springer, C., \& Van Der Zee, K. (2013). Managing a culturally diverse workforce: Diversity perspectives in organizations. International Journal of Intercultural Relations, 37(2), 159-175.

Prajogo, D. I. (2016). The strategic fit between innovation strategies and business environment in delivering business performance. International Journal of Production Economics, 171, 241-249.

Prajogo, D. I., \& Ahmed, P. K. (2006). Relationships between innovation stimulus, innovation capacity, and innovation performance. $R \& D$ Management, 36(5), 499-515.

Prajogo, D. I., \& Ahmed, P. K. (2007). The relationships between quality, innovation and business performance: an empirical study. International Journal of Business Performance Management, 9(4), 380-405.

Rangus, K., \& Slavec, A. (2017). The interplay of decentralization, employee involvement and absorptive capacity on firms' innovation and business performance. Technological Forecasting and Social Change, 120, 195-203. 
Raza, I., \& Tariq, F. (2016). Effect of HR diversity management practices on employee knowledge sharing: Examining the mediating role of trust on leadership and moderating role of cooperative norms. IBT Journal of Business Studies (JBS), 12(1).

Reave, L. (2005). Spiritual Values and Practices Related to Leadership Effectiveness, The Leadership Quarterly, 16, 655-687.

Rijamampianina, R. ve Carmichael, T. (2005). General Issues in Management: A Pragmatic and Holistic Approach to Managing Diversity. Problems and Perspectives in Management. 1.

Roberts, E.B., \& Hauptman, O. (1987). The financing threshold effect on success and failure of biomedical and pharmaceutical start-ups. Management Science, 33(3), 381-394.

Samur, S. B. (2011). The mediating role of innovative work behaviors between intrapreneurial climate and organizational innovativeness: An empiricial study. Yaşar Üniversitesi Sosyal Bilimler Enstitüsü, Yayımlamış Yüksek Lisans Tezi, İzmir.

Saruhan, S. C., \& Yıldız, M. L. (2009). Çă̆daş Yönetim Bilimi. İstanbul: Beta Basım Yayım Dağıtım A.Ş.

Schermelleh-Engel, K., Moosbrugger, H., \& Müller, H. (2003). Evaluating the fit of structural equation models: Tests of significance and descriptive goodness-of-fit measures. Methods of psychological research online, 8(2), 23-74.

Schoonhoven, C.B., Eisenhardt, K.M., \& Lyman, K. (1990). Speeding products to market: Waiting time to first product introduction in new firms. Administrative Science Quarterly, 177-207.

Selome, G. J. (2008). The relationship between diversity climate perceptions and turnover intentions (Doctoral dissertation, University of Pretoria).

Seong, J. Y., \& Hong, D. S. (2018). Age diversity, group organisational citizenship behaviour, and group performance: Exploring the moderating role of charismatic leadership and participation in decision-making. Human Resource Management Journal, 28(4), 621640.

Shamir, B. (1995), Social Distance and Charisma: Theoretical Notes and An Exploratory Study. Leasdership Quaterly, 6 (1), 19-47.

Shamir, B., House, R. J., \& Arthur, M. B. (1993). The motivational effects of charismatic leadership: A self-concept theory. Organization Science, 4(4), 577-594.

Shan, P., Song, M., \& Ju, X. (2016). Entrepreneurial orientation and performance: Is innovation speed a missing link?. Journal of Business Research, 69(2), 683-690.

Soto-Acosta, P., Popa, S., \& Palacios-Marqués, D. (2016). E-business, organizational innovation and firm performance in manufacturing SMEs: an empirical study in Spain. Technological and Economic Development of Economy, 22(6), 885-904. 
Tavşancıl, E. (2002). Tutumların ölçülmesi ve SPSS ile veri analizi. Nobel Yayıncılık, Ankara.

Thomas, J. R., Nelson, J. K., \& Silverman, S. J. (2015). Research methods in physical activity. Human kinetics.

Thomas, R. R. (1990). From affirmoiive aciion to affirming diversity. Harvard business review, $1,107 \mathrm{~A} 117$.

Thomas, R. R. (2004). Diversity management and affirmative action: Past, present and future. Diversity Symposium - 7.10.2004, R. Thomas \& Associates, Inc.

van Gool, R. J. M. (2019). Leading into job crafting A study examining the relationships between charismatic leadership, well-being and innovative work behavior and the mediating role of job crafting (Master's thesis).

Venkatraman, N., \& Ramanujam, V. (1986). Measurement of business performance in strategy research: A comparison of approaches. Academy of management review, 11(4), 801-814.

Vesey, J.T. (1991). The new competitors: They think in terms of "speed-to-market". The Executive, 5(2), 23-33.

Villamil, A. M. (2007). Perceptions of diversity management and organizational attractiveness: Exploring the effects of gender, ethnicity, and type of recruitment advertisement (Doctoral dissertation, University of Kansas).

Vlachos, P. A., Panagopoulos, N. G., \& Rapp, A. A. (2013). Feeling good by doing good: Employee CSR-induced attributions, job satisfaction, and the role of charismatic leadership. Journal of business ethics, 118(3), 577-588.

Weber, M. (1968). On Charisma and Institution Building. University of Chicago Press.

Wentling, R. M., \& Nilda, P. R. (2000). Current status of diversity initiatives in selected multinational corporations. Human Resource Development Quarterly, 11(1) 35-60.

Willner, A. R. (1985). The spellbinders: Charismatic political leadership. Yale University Press.

Zahra, S. A., \& Covin, J. G. (1993). Business strategy, technology policy and firm performance. Strategic management journal, 14(6), 451-478.

Zehir, C., Erdogan, E., \& Basar, D. (2011). The relationship among charismatic leadership, ethical climate, job satisfaction and organizational commitment in companies. Journal of Global Strategic Management, 10, 49-59. 